\title{
TUHAN DALAM BUKU BASIC CONCEPT OF THE QURAN KARYA ABUL KALAM AZAD
}

\author{
Dakhirotul Ilmiyah \\ Universitas Islam Negeri Sunan Ampel Surabaya \\ dakhirotul@uinsby.ac.id
}

\begin{abstract}
This paper examines the concept of God according to Abul Kalam Azad as it is expressed textually in his book Basic Concept of the Quran. It further elaborates on how does Abul Kalam Azad understand the concept of Divinity and how does he construct it as a basic value of human life. He argues that the One was the very first of human belief in God. It was later that the initial belief in God took a retrogressive turn, where the common people attempt to bodying the Almighty Being into some attributes for the sake of analogy of their own qualities. This idea suggests that Azad was of scholars who holds that the archeology of human belief in the divinity of God is originated from the belief in the One. Azad has also argued that both verses of QS. 10: 19 and QS. 2: 213, which literally refer to "one single community", alluded to refer as "one religion", which means "One God." This typical of language game which played by Azad has significantly contributed to favor his idea on monotheism and the Oneness of God.
\end{abstract}

Keywords: Abul Kalam Azad, Theology, God, Monotheism.

Abstrak: Artikel ini membahas tentang konsep ketuhanan menurut Abul Kalam Azad yang diungkapkan secara tekstual dalam bukunya Basic Concept of the Qur'an. Tulisan ini lebih lanjut juga mengurai bagaimana Abul Kalam Azad memahami konsep Ketuhanan dan bagaimana ia mengkonstruksinya sebagai nilai dasar kehidupan manusia. Dia berpendapat bahwa ke-Esa-an pada dasarnya adalah bentuk kepercayaan manusia paling awal terhadap Tuhan. Belakangan, kepercayaan tersebut mengalami kemunduran, di mana orang-orang awam berusaha untuk mengimajikan Tuhan ke dalam atribut-atribut analogis sesuai dengan kualitas intelektualisme mereka. Ide ini menunjukkan bahwa Azad adalah seorang sarjana yang berpendapat bahwa arkeologi kepercayaan manusia pada keilahian Tuhan bermula dari kepercayaan akan yang Esa. Azad juga berpendapat bahwa kedua ayat QS. 10:19 dan QS. 2:213, yang secara harfiah merujuk pada "satu komunitas tunggal," dimaknai sebagai "satu agama," yang berarti 
"Satu Tuhan." "Permainan Bahasa" yang dilakukan oleh Azad ini jelas berkontribusi signifikan untuk mendukung idenya tentang monoteisme dan Keesaan Tuhan.

Kata Kunci : Abul Kalam Azad, Teologi, Tuhan, Monoteisme.

\section{Pendahuluan}

Kajian tentang konsep Ketuhanan merupakan kajian pokok dalam mempelajari satu agama. Konsep ketuhanan yang di yakini oleh umat Kristen, Islam, Budha dan Hindu mempunyai penafsiran yang berbeda-beda atas zat atau sifat yang ada pada diri-Nya. Kajian ini memang sering dilakukan karena menjadi suatu pokok dalam ajaran agama-agama. Semua agama mempunyai Tuhan dan memiliki interpretasi beragama tentang entitas ke-Tuhan-an.

Dalam diskursus keislaman, tema tentang ketuhanan menjadi satu topik yang tidak terputus dalam pembahasannya. Fazlur Rahman, misalnya, dalam bukunya Major Themes of the Qur'an, mengawali kajian pembahasan tematiknya dengan tema tentang Tuhan (God). ${ }^{1}$ Menurutnya, tema ketuhanan merupakan tema paling sentral dalam Alquran. Kata Allah sendiri disebut tidak kurang dari 2500 kali dalam Alquran, dan itu belum dihitung dengan diksi-diksi lain yang merujuk pada makna Tuhan, seperti al-Rabb dan al-Rabim. Di sisi lain, tema ketuhanan menjadi penanda karakteristik ayat-ayat awal Alquran periode Mekkah yang menurut Theodore Noldeke sebagai "the single, higher goal of Muhammad in the Meccan suras," di mana Muhammad mulai mendakwahkan teologi monoteisme (Satu Tuhan) kepada masyarakat Mekkah saat itu. Selebihnya, secara semantik Izutsu juga menekankan sentralitas tema ketuhanan dalam Alquran dengan menyatakan bahwa "Allah is the bighest focus-word in the vocabulary of the Qur'an, presiding over all the semantic fields and, consequently, the entire system."

Berbeda dengan beberapa sarjana lain, nama Abul Kalam Azad bisa disebut sebagai sarjana yang memiliki concern dalam studi keislaman dengna wajah yang cukup baru. Terlebih jika kita memposisikan karyanya dalam milieu dan konteks spesifik perjuangan kemerdekaan India, di mana dia tidak hanya sebagai seorang sarjana,

\footnotetext{
${ }^{1}$ Fazlur Rahman, Major Themes of the Qur'an (Chicago: The University of Chicago Press, 2009), 1.

2 Theodor Noldeke, Friedrich Schwally, Gotthelf Bergstrasser, Otto Pretzl, The History of the Qur'an, ed. \& terj. Wolfgang H. Behn (Leiden: Brill, 2013), 59.

3 Toshihiko Izutsu, God and Man in the Qur'an Semantics of the Qur'anic Weltenschanung (Tokyo: Keio University, 1964), 76.
} 
teolog, namun juga sebagai seorang aktivis. Dalam karyanya Basic Concept of the Qur'an, uraian tentang ketuhanan dalam Alquran tidak lagi dilihat olehnya secara tematik rigid, sebagaimana Rahman, juga tidak dilihat secara kronologis, sebagaimana Noldeke, dan tidak juga secara semantik, seperti Izutsu. Dalam uraiannya, Azad lebih mengedepankan nuansa rasional filosofis, dengan cukup memberikan penekanan pada aspek arkeologis. Perspektif inilah yang bisa dikatakan sesuatu yang baru dari pemikiran Azad yang akan dieskplorasi lebih jauh dalam artikel ini.

Beberapa sarjana seperti Hayat Alvi ${ }^{4}$ S. A. Kamali ${ }^{5}$ John Willis ${ }^{6}$, S. Irfan Habib ${ }^{7}$, Ian H. Douglas ${ }^{8}$ telah mengkaji Abul Kalam Azad secara teliti. Namun sejauh pembacaan penulis, fokus kajian terhadap Azad dari pemikirannya tentang Tuhan dan ketuhanan belum mendapat perhatian secara serius dari kalangan sarjana-sarjana di atas. Barangkali, S. A. Kamali merupakan sarjana yang sedikit menyinggung tentang teologi dan pentingnya Tuhan dalam sistem teologi manusia dalam tulisan-tulisan Azad. Hanya saja, Kamali hanya menyinggung dalam uraiannya secara sederhana, hanya satu lembar, yang tentu ini membutuhkan elaborasi lebih lanjut. Tulisan ini hendak mengisi gap akademik tersebut dengan melakukan elaborasi secara mendalam terkait dengan konsep Tuhan dalam perspetif Abul Kalam Azad.

\section{Biografi Abul Kalam Azad}

Abul kalam Azad lahir pada tahun 1888 di Makkah. Orang tua Abul Kalam Azad merupakan seoarang ulama yang bermigrasi ke Makkah setelah gagal melakukan aksi pemberontakan 1857 terhadap kekuasaan Inggris di India (British East India Company). Abul Kalam Azad saat muda telah jauh melampaui teman-teman sekolahnya. Dia unggul dalam hampir semua kurikulum yang ditawarkan di sekolah

\footnotetext{
${ }^{4}$ Hayat Alvi, "The Islamic Principles of Social Justice: Maulana Abul Kalam Azad and Nonviolent Civil Disobedience," Contemporary Review of the Middle East, 2, 1\&2, (2015), 14-30.

5 S.A. Kamali, “Abul Kalam Azad's Commentary on the Qur'an," The Muslim World, Vol. 49, No. 1 (1959), 5-18.

${ }^{6}$ John Willis, "Debating the Caliphate: Islam and Nation in the Work of Rashid Rida and Abul Kalam Azad," The International History Review, 32, 4 (2010), 711-732.

7 S. Irfan Habib, "Maulana Abul Kalam Azad and His Ideas about the National Education System," Contemporary Education Dialogue, 12, 2 (2015), 238-257.

8 Ian H. Douglas, "Abul Kalam Azad and Pakistan A Post-Bangladesh Reconsideration of an Indian Muslim's Opposition to Partition," Journal of the American Academy of Religion, vol. XL, no. 4 (1972), 458-479.
} 
Dars-i-Niqami di Kalkuta. Di sekolahan tersebut, sebagai seorang siswa dia telah belajar banyak tentang pelajaran-pelajaran mendasar keislaman seperti teologi Islam, hadis, fikih, filsafat, tasawuf, sejarah, dan juga ilmu-ilmu lain seperti geografi, matematika, dan hokum, selain juga ilmu-ilmu kebahasaan seperti Arab, Persia, dan Urdu. Bahkan, dia menyelesaikan semua kurikulum tersebut hanya dalam waktu empat tahun, dari yang semestinya ditempuh dalam waktu empat belas tahun. ${ }^{9}$

Pada tahap selanjutnya, Azad melanjutkan bangku pendidikannya di Makkah dan setelah itu melanjutkan studinya di Al-Azhar Kairo. Setelah orang tuanya meninggal, dia pergi ke India dan menetap di sana untuk selamanya. ${ }^{10}$ Di perguruan-perguruan Makkah dan Kairo dia hanya memperoleh pengetahuan bahasa Arab dan Agama. Karena merasa ilmu pengetahuan tentang keilmuan barat kurang lalu dia tambahkan pengetahuan bahasa Inggris dan ilmu-ilmu pengetahuan modern Barat, yang dipelajarinya atas usaha sendiri, setelah berada di India. Dia tidak ingin menjadi ulama seperti orang tuanya, tetapi bercita-cita menjadi pengarang dan politikus. ${ }^{11}$

Pada usia yang muda ia sudah memilih jalannya untuk berjuang dengan pena. Dalam segala bidang, ia merupakan anak yang cerdas dan luar biasa. Di usia dua belasan tahun ia ingin menulis riwayat hidup Al-Ghazali. Dua tahun kemudian ia menulis artikel-artikel ilmiah di majalah Makhæan, majalah sastra yang paling baik dan cukup mentereng pada waktu itu. Ia juga menghadiri pertemuan-pertemuan nasional, dan orang-orang merasa heran melihat anak muda yang masih berusia belasan tahun itu ikut aktif dalam dunia sastra. Melihat tulisan Abul Kalam Azad tentang sastranya yang dinilai cukup baik dan serius, mereka menyangka bahwa Azad, penulis sastra tersebut, adalah orang dewasa, tapi nyatanya mereka berhadapan dengan anak yang berusia enam belas tahun. ${ }^{12}$

Abul Kalam Azad muda pada tahun 1912 telah menerbitkan suatu majalah di Kalkutta yang bernama Al-Hilal. Pada mulanya majalah itu berjumlah sebelasa ribu tetapi kemudian meningkat menjadi dua puluh lima ribu. Di majalah inilah Abul Kalam Azad

\footnotetext{
9 A.B. Rajput, Maulana Abul Kalam Azad (Lahore, Lion Press, 1957), 18; Alvi, "The Islamic Principles," 16.

${ }^{10}$ Harun Nasution, Pembaharuan dalam Islam (Jakarta; Bulan Bintang, 1991), 202.

11 Ibid.

12 Mukti Ali, Alam Pikiran Islam Modern di India dan Pakistan, cet. III (Bandun; Mizan, 1996), 148.
} 
mengeluarkan ide-idenya mengenai agama yang pada waktu itu mengejutkan bagi golongan ulama. Al-Hilal juga berisi tentang politik dan karena serangan dan kritiknya yang tajam terhadap pemerintahan Inggris lalu majalah Al-Hilal akhirnya dilarang untuk terbit. ${ }^{13}$

Pemikiran Abul Kalam Azad dalam bidang agama tidak begitu liberal seperti pemikiran Ahmad Khan. Sebagai murid Sibli, pembaharuanya kelihatan bersifat moderat. Tujuan eksplisit yang terlihat pada majalah Al-Hilal ialah bahwa dia berkehendak untuk melepaskan umat Islam dari pemikiran-pemikiran abad pertengahan dan taklid, sebuah paradigma yang menjadi gejala umum pada masanya. ${ }^{14}$

Ia menganjurkan untuk kembali kepada Alquran dan untuk keperluan ini Abul Kalam Azad menerjemahkan Alquran ke dalam bahasa Urdu dengan diberi tafsiran. Alquran harus dipahami sebagaimana dia terlepas dari pengaruh pemikiran ahli hukum, sufi, teolog, filosof, dan sebagainya. Dengan kata lain, dia ingin mengembalikan Alquran sebagaimana fungsinya, tanpa warna. Karena menurutnya, warna-warna tersebut telah banyak mengecohkan Alquran dari fungsi yang semestinya diemban dan disampaikan oleh Alquran kepada manusia.

Umat Islam mengalami kemunduran dikarenakan oleh dogmatisme dan sikap taklid yang berlebihan. Selain itu, kemunduran juga disebabkan oleh keadaan umat Islam yang tidak lagi seluruhnya menjalankan ajaran-ajaran Islam. Kebangkitan umat Islam dapat diwujudkan selain dengan melepaskan diri dari faham-faham usang, juga dengan melaksankan ajaran Islam dalam segala bidang kehidupan umat. Dan kekuatan umat Islam akan timbul kembali dengan memperkuat tali persaudaraan dan persatuan umat Islam seluruh dunia. $^{15}$

Azad sendiri merupakan seorang pejuang. Dia telah banyak menghabiskan waktu di penjara dan sistem peradilan Inggris, sehingga dia merupakan orang yang mengalami secara langsung bagaimana bentuk-bentuk opresi dari penjajah. Dia menyebut dalam Qaul-I Faisal,

\footnotetext{
13 Nasution, Pembaharuan dalam Islam, 203.

${ }^{14}$ Lihat misalnya pemikiran Ami $>\mathrm{n}$ al-Khu $>\mathrm{li}>$ yang menyatakan "awwal al-tajdi $>\mathrm{d}$ qatl al-qadi $>$ m fahman" (awal mula sebuah pembaruan adalah memotong pemahaman masa lalu). Ami $>\mathrm{n}$ al-Khu $>\mathrm{li}>$, Mana $>$ hij al-Tajdi $>d$ fi $>$ al-Nah $\}$ w wa alBala $>$ ghah wa al-Tafsi $>r$ wa al $-A<d a>b$ (Mesir: Da $>$ r al-Ma'rifah, 1961).

${ }^{15}$ Nasution, Pembaharuan dalam Islam, 203.
} 
"selama empat tahun saya mengalami pengasingan."16 Rajput juga menggambarkan pribadi Azad sebagai berikut:

Instead of sitting in a cozy seat of a spiritual leader, he adopted a harder, difficult and strenuous way of life to save the masses from the pitfalls of blind dogmatic superstitions and lead them toward an enlightened and broadminded faith; to free the minds of his country-men of all that makes for inter-communal misunderstandings, and to inspire them by his own examples of hardships and sacrifices. ${ }^{17}$

Intelektualisme dan aktivisme yang berpadu erat dalam personalitas Azad, menjadikannya sebagai seorang sarjana yang disegani. Hal itu terlihat ketika paska kemerdekaan India pada tahun 1927, Abul Kalam Azad diangkat menjadi menteri pendidikan hingga ia tutup usia pada tahun 1958. Selama karirnya, Abul Kalam Azad merespon secara baik masalah pendidikan kaum muslimin di India yang diarahkan pada dasar keislaman. Seperti paradigmanya yang telah dikemukakan di awal, bahwa kemunduran Islam adalah karena umat Islam itu sendiri yang banyak melakukan taklid buta dan perlu untuk mandiri dalam berijtihad menentukan kuasa hukum dan otoritas yang kontekstual pada masanya. Pada praktinya, Azad lebih tertarik pada pemikiran-pemikiran Barat, seperti diterimanya bahasa Latin untuk bahasa Urdu serta bahasa India lainya. Ia juga mendukung pemerintahan dalam mensponsori keluarga berencana. ${ }^{18}$

\section{Tafsir Tarjumān Al-Qur'ān dan Basic Concept of the Qur'an}

Kitab Tarjumān Al-Qur'an merupakan magnum opus Abul Kalam Azad. Karya ini ditulis oleh Azad sebagai bentuk tanggungjawab sosial dan intelektualnya. Jika ditanya mengapa tafsir Alquran, maka akan kita dapati dalam pemikirannya bahwa Alquran merupakan sumber utama umat Islam. Alquran merupakan sumber gerakan sekaligus motivasi pergerakan. Alquran merupakan sumber paling utama dalam basis konstruksi keislaman. Jika cabang-cabang keilmuan itu kini banyak mewarnai iklim intelektual Islam, sejatinya semua itu merujuk dan kembali pada Alquran. Di sinilah kemudian letak sentralitas

16 Rajput, Maulana Abul Kalam, 93.

17 Ibid., 25-26.

18 Margareta Marcus, Islam dan Modernisasi, terj. A. Jainuri (Surabaya: Usaha Nasional, 1982), 101-102. 
Alquran yang ingin dikembalikan oleh Azad dengan menulis sebuah karya tentang Alquran.

Dalam kata pengantar yang ditulisnya, dia menyebut keinginannya untuk menulis tiga subjek tentang Alquran: terjemah Alquran, tafsir Alquran, dan prolegomena (pengantar) untuk tafsir. Ketiganya, menurutnya, akan mampu menjangkau tiga level masyarakat yang memiliki latarbelakang berbeda dalam intelektualismenya terhadap Alquran. Terjemah Alquran ditujukan kepada masyarakat umum, tafsir ditujukan kepada mereka yang hendak mengkaji Alquran dengan lebih detail, dan prolegomena ditujukan bagi sarjana Alquran. ${ }^{19}$

Turjumān al-Qur'an sendiri tidak sama seperti awal pula diinginkan. Dalam bentuk cetakan saat ini, karya tersebut terdiri dari dua volume yang dipublikasikan pada tahun 1930 dan 1936, namun kemudian karya tersebut direvisi dan dicetak ulang pada tahun 1945. Volume pertama, yang berisi 475 halaman, memuat teks dan terjemah dari 6 surah pertama Alquran. Penafsiran Azad terhadap surah al-Fatihah memiliki porsi lebih karena menghabiskan hamper separuh halaman dari volume pertama tersebut. Tafsir surah al-Fatihah yang memakan 224 halaman inilah yang kemudian disebut oleh Azad sebagai "the prolegomena." Adapun pada tafsir surah-surah selanjutnya, para pembaca hanya disuguhkan terjemah Alquran yang ditambahi dengan beberapa anotasi sebagai keterangan tambahan atas terjemah tersebut. Sedangkan volume kedua, karya Turjumān al-Qur'an ini dicetak dengan menghabiskan 544 halaman yang berisi tentang terjamahan Alquran hingga juz ke-18. ${ }^{20}$

Terkait dengan banyaknya halaman dalam menafsirkan surah alFatihah, Azad menjelaskan

"I realized that I could not control the movement of my pen. The thing went on. Feeling that the commentary of the surah alFatihah was of primary importance to the interpretation of the Qur'an I gave it my prior attention." 21

Karya Basic Concept of the Qur'an sendiri merupakan rangkuman dari Turjumān al-Qur'an yang disendirikan, khusus untuk tafsir atas

19 Mawlana Abul Kalam Azad, The Tarjumān Al-Qur'ān, terj. Syed Abdul latif (Hiderabad: Syed Abdul Latif Trust for Qur'anic \& Other Cultural Studies, 1962), xxvi.

${ }^{20}$ Kamali, "Abul Kalam Azad’s Commentary," 6-7.

21 Azad, The Tarjumān, xxx. 
surah al-Fätihah. Karya ini telah mengalami penerjemahan ke dalam Bahasa Inggris, namun tetap di bawah pengawasan Azad. Karya tersebut disusun dalam bentuk yang sederhana dengan tujuan untuk bisa mengantarkan kajian-kajian alamiyah terhadap Alquran. Di dalamnya, Abul Kalam Azad telah menyatakan dan merangkai semua masalah utama yang timbul dari kajian Alquran, kecuali dalam hal-hal yang khusus dan yang menyinggung sifat Allah dikarenakan untuk sifat ini telah diupayakan suatu studi perbandingan mengenai pendekatan-pendekatan atasnya oleh berbagai filsafat dan agama. ${ }^{22}$

Surah al-Fätihah merupakan awal dari runtutan mushaf Alquran. Dengan alasan ini, surah ini dijuluki dengan Fätihat al-Kitāb atau pembukaan kitab. Dikarenakan nilai interaksinya, surah ini dianugerahi dengan posisi terhormat dalam Alquran dan kehormatan untuk tampil pada halaman permulaan. Alquran mengakui akan pentingnya surah ini sehingga disebut dalam surah yang lain :

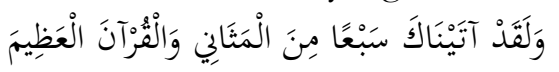

"Dan Sesungguhnya Kami telah berikan kepadamu tujuh ayat yang dibaca berulang-ulang dan Alquran yang agung. (QS. alHijr : 87)."

Menurut Abul Kalam Azad, Hadis dan syarat ayat diatas yakni yang dimaksud dengan tujuh ayat tersebut adalah surah Al-Fatihah. Walaupun surah ini hanya terdiri dari tujuh ayat tapi dibaca berulangulang dalam salat lima waktu. Surah ini juga disebut sebagai $S a b^{\prime}$ alMathāin (tujuh yang dibaca berulang-ulang). ${ }^{23}$

Kesalahan terbesar yang telah dibuat oleh manusia dalam pendekatan mengenai konsep Tuhan adalah bahwa manusia terlalu sering mengganggap Tuhan sebagai Tuhan terror, bukan Tuhan cinta. Kata pertama atau lafadz pertama surah ini membeberkan penyimpangan kebenaran yang telah berlangsung lama. Dengan memaulai hamd atau pujian bagi Tuhan, itu menunjukkan bahwa pujian tersebut termasuk pujian yang indah hanya mungkin diitujukan kepada sesuatu yang benar-benar indah dan bagus. Maka kata tersebut tidak bisa menampung tentang konsep Tuhan terror.

\footnotetext{
22 Maulana Abul Kalam Azad, Hikmah al-Fatiha: Konsep Tuhan dalam Al-Quran. Terj. Tim Mushaf (Depok: Mushaf, 2007), xxxii-xxxiii.

${ }^{23}$ Ibid., 19-20.
} 
Setelah hamd, surah tersebut kemudian menarik perhatian pada ke-maha pemurahan Tuhan. Dengan demikian, Kemurahan dan keadailan-Nya memberikan gambaran lengkap mengenai julukan Ilahiyah yang berfungsi untuk melengkapi manusia dengan semua yang dibutuhkanya untuk mempertahankan dan mengembangkan umat manusia dan mencegah agar dia tidak terjerumus.

Kemudian dengan menjuluki Tuhan Rab al-Alamin atas Raja dari semua bentuk kehidupan, kata tersebut mendesak kita untuk mengakui sifat universal dari perhatian Ilahi terhadap setiap individu, kelompok, masyarakat, Negara, dan setiap bentuk keberadaan lainya.

Secara umum, upaya penafsiran yang dilakukan oleh Azad berangkat dari kenyataan tafsir-tafsir yang telah beredar pada masanya. Dia melihat ada banyak tafsir yang menurutnya justru jauh dari format ideal sebuah penafsiran Alquran. Setidaknya, ada dua poin penting dalam episteme pemikiran tafsirnya: pertama, bahwa tafsir ideal itu mampu merefleksikan pendekatan yang dilakukan oleh nabi dan para sahabat. Kedua, bahwa tafsir yang ideal itu mampu menghadirkan kembali konteks di mana Alquran turun dan berinteraksi dengan audiens awal Alquan, seperti nabi, para sahabat dan masyarakat Arab secara luas. Seperti ditegaskan oleh Kamali, bahwa Azad menilai, "the farther a commentator is removed from the earliest age (Sadr-i-Awwal), the stronger and more pronounced is his incapacity to grasp the reality of the Holy Book (semakin jauh seorang mufasir terdampar dari era awal, semakin kuat ketidakmampuannya dalam memahami realitas kitab suci)." Dari sini kita bisa melihat bahwa Azad, sebagaimana para pemikir Alquran modern, menekankan pentingnya konteks Alquran dalam melakukan reinterpretasi terhadap Alquran.

Lebih jauh, kegelisahan Azad tampak dari uraiannya sebagai berikut:

"When we look back into the history of the commentators of the Qur'an from the earliest centuries of Islam right up to the close of the last century, we find that the standard of approach to the meaning of the Qur'an had steadily deteriorated. This was the result of a gradual decadence in the quality of the Muslim mind itself. When the commentators found that they could not rise to the heights of the Qur'anic thought, they strove to bring it down to the level of their own mind. If we are to see the Qur'an in its true light, it will be necessary for us to lift all those veils which have, from age to age, been laid thereon under the stress of 
influences alien to the spirit of the Qur'an, and then search for the reality about it in its own pages." 24

Dari statemen ini, kita bisa menggarisbawahi bahwa asumsi otoritas keilmuan yang paling otoritatif, khususnya dalam penafsiran Alquran, adalah pada masa nabi dan sahabat. Pernyataan Azad di atas menunjukan bahwa pendekatan standar terhadap Alquran telah mengalami proses yang memburuk dari masa ke masa. Hal itu disebabkan karena terputusnya konteks yang melatari Alquran ketika turun dengan konteks para penafsir Alquran. Konteks inilah yang dinilai Azad kurang mendapat perhatian sehingga tidak cukup dihadirkan secara utuh ketika menafsirkan Alquran. Selain itu, dia juga menyatakan bahwa hal ini terjadi karena degradasi kualitas intelektual umat Muslim yang terjadi dari waktu ke waktu.

Selebihnya, Azad menjelaskan beberapa fakta untuk mengilustrasikan dan menjelaskan posisi penafsiran yang dipahaminya, sebagaimana telah dirangkum oleh Kamali. ${ }^{25}$

1. Orang-orang yang dituju secara langsung (khitāb) Alquran itu memiliki pikiran yang sederhana. Karenanya, gaya Bahasa dan bicara yang digunakan Alquran itu merupakan style yang sederhana yang dapat dipahami secara langsung oleh mereka. Tapi seiring berjalannya waktu, pengaruh dari Persia, budaya Romawi dan ilmu pengetahuan Yunani menghancurkan sifat dasar kesederhanaan tersebut.

2. Biasanya, sebuah kitab paling baik dipahami oleh murid-murid "pemilik Kitab" (Nabi). Para mufasir generasi setelahnya sepertinya mengabaikan fakta ini. Hal itu nampak ketika mereka justru memberi pujian berlebih kepada para pendahulu (salaf) pada aspek "kesalehan" semata dan tidak memberi perhatian lebih pada aspek pengetahuannya.

3. Legenda yang popular di kalangan Muslim baru (converted Muslim) telah dimasukan ke dalam tafsir.

4. Prinsip untuk merujuk secara langsung pada murid-murid nabi diabaikan. Mereka masih menghormati 'takhayul' otoritas mereka yang menyebabkan mereka banyak menerima

24 Azad, The Tarjumān, xxxi-xxxii.

${ }^{25}$ Kamali, "Abul Kalam Azad's Commentary," 7-8. 
penafsiran yang sebenarnya diragukan (apokrifa) dari otoritas tersebut.

5. Orang-orang tidak bisa melihat metode argumen Alquran. Upaya yang 'konyol' untuk membaca seluk-beluk logika Alquran mengakibatkan penyimpangan dari realitas yang terkandung di dalamnya.

6. Kata-kata sederhana yang digunakan dalam Alquran, seperti khulüd (permanen), aḅād (yang Esa), mathäl (contoh), ḅujah (bukti), burbān (argumen), ta'ìil (penafsiran), pengertiannya berkembang secara teknis yang mungkin maknanya tidak terbayangkan ada pada masa awalnya.

7. Berkembangnya asumsi bahwa tidak ada perselisihan antara ajaran Alquran dan penemuan ilmiah.

8. Para mufasir tidak mengakui dengan cukup jelas bahwa, seperti semua ajaran lainnya, ajaran Alquran berkisar pada beberapa ide sentral dan prinsip dasar.

9. Dalam banyak kasus, para mufasir tidak memiliki naluri untuk mengapresiasi idiom bahasa Arab.

10. Meski secara umum para ulama Muslim tidak mengalah pada pengaruh politik yang mengancam akan mengganggu keutuhan penilaian individunya, namun pikiran mereka tidak bisa sepenuhnya tertutup. Akibatnya, faktor lokal entah bagaimana cukup mewarnai pandangan mereka tentang Alquran.

11. Sejak abad ke-4 dan seterusnya, otoritarianisme adalah tatanan zaman sekarang. Hak untuk berijtihad tidak digunakan lagi, dan para mufasir yang hebat menyia-nyiakan sumber daya mereka untuk hal-hal yang tidak jelas.

12. Ketidakjelasan dan ketaatan pada otoritas menyebabkan hal-hal yang ganjil seperti popularitas Al-Sakkāki, Al-Taftāzāni, AlBayḍāâi, dan dua Jalāl (Jalāl al-Dìn al-Maḥalli dan Jalāl al-Dìn al-Suyūtịi).

13. Dalam Tafsir yang paling populer, interpretasi yang paling tipis dan paling tidak tepat justru dipilih. 
14. Tafsir bi al-ra'y (interpretasi berbasis akal) membuka pintu untuk semua kesulitan dan kontradiksi yang ada dalam Kitab Suci.

\section{Konsep Tuhan Dalam Basic Concept of Quran}

Mempelajari suatu agama, aspek yang pertama-tama harus dikaji dari agama tersebut adalah konsep ketuhanan yang ada dalam agama tersebut. Karena tujuan dari mengakaji konsep ketuhanan adalah untuk memberikan ukuran mengenai agama atau nilai agama tersebut bagi kehidupan. ${ }^{26}$

Ide atau pengertian mengenai Tuhan telah menjalani sejarah yang panjang dan berliku-liku. Orang dapat tergoda untuk menganologikan proses yang mendasari pembentukan pemahaman ini dengan proses evolusi yang umum. Namun biar pun kedengaranya sangat ganjil, proses yang terjadi adalah justru sebaliknya. Kepercayaan akan keberadaan Tuhan, begitu dikatakan oleh Azad, tidak pernah merupakan hasil dari perkembangan pemikiran manusia, yang dapat ditelusuri perkembanganya dari awal. ${ }^{27}$

Kepercayaan ini sudah ada dalam diri manusia dan tak terpisahkan dari sifat dasar yang ada pada manusia yang pertama kali mengenai Tuhan adalah gambaran akan sifat tunggal-Nya, akan keEsa-an-Nya. Gambaran akan suatu kekuasaan maha besar yang semestinya telah menciptakan semua yang ada di sekitarnya, yang dapat dilihat dan diraba serta dirasakanya. Kemudian secara perlahanlahan gambaran ini mengalami perubahan ditandai oleh suatu kemunduran dan munculnya konsep banyak tuhan atau politeisme. Dengan kata lain, alih-alih mengalami evolusi, sejarah teisme menjalani gerakan mundur, hanya dalam hal ini sifat-sifat Ketuhanan, teori evolusi, mungkin dapat memberikan bantuan yang berarti pada usaha penelitian ini.

Azad menyebut bahwa,

The urge among European scholars to treat monotheism as the result of an evolutionary process had its rise about the close of the 18th century. But it was during the second half of the 19th century that most of the theories upholding the idea were formulated. Attempts were made to locate the origin of the belief in God severally in nature myths, fetish worship, worship of ancestors, primitive animism, astral and nature mythology, necromancy and

${ }^{26}$ Abul Kalam Azad, Konsep Dasar Al-Quran, Terj. Ary Anggari H (Jakarta: Pustaka Firdaus, 1991), 1.

27 Ibid. 
so forth. The idea which the different theories nursed was that even as every other phenomenon in life, monotheism was the result of an evolutionary process..$^{28}$

Dorongan untuk menganggap monoteisme sebagai hasil proses evolusi di kalangan cendekiawan Eropa muncul pada sekitar akhir abad ke-18. Namun baru pada paruh kedua abad ke-19 sebagian besar teori tersebut di formulasikan. Usaha-usaha dilakukan di antaranya untuk menemukan asal-usul kepercayaan kepada Tuhan dalam mitos tentang alam, pemujaan berhala, pemujaan nenek moyang, nimisme primitif, mitologi tentang alam dan benda-benda langit. Gagasan yang dicoba dipertahankan oleh berbagai teori tersebut adalah bahwa sebagaimana halnya setiap gejala dalam kehidupan, monoteisme adalah juga hasil dari suatu proses evolusi. ${ }^{29}$

Penemuan-penemuan revolusioner di abad ke-20 segera mementahkan ide ini. Penelitian-penelitian yang dilakukan pada sukusuku pribumi di Australia Tenggara dan beberapa pulau di Samudra Pasifik, seperti juga suku-suku primitif di Amerika Utara yang sejak zaman entah kapan telah mengamati bentuk-bentuk kehidupan yang paling primitif yang ditandai dengang adaya tanda perkembangan evolusi apa pun pada aspek cultural mereka, ditambah dengan penelitian-penelitian kepurbakalaan di Mesir dan pengalian-pengalian di Irak dan Mohenjodaro, semuanya menunjukkn bahwa kepercayaan akan adanya dasar yang mutlak bagi segala sesuatu bukanlah hasil dari proses evolusi. Studi mutakhir mengenai bangsa Semit juga mendukung pandangan ini. Studi-studi tersebut mengungkapkan bahwa suku-suku Semit pada mulanya percaya akan suatu Makhluk Maha Tinggi yang tak kelihatan. ${ }^{30}$

Sebelum Alquran diturunkan, tingkatan tertinggi yang dapat dicapai oleh pemikiran manusia adalah membayangkan citra Tuhan tanpa bantuan lambang apapun. Akan tetapi, dalam hal sifat-sifat Ketuhanan, tidak ada satu pun gagasan yang dapat memberikan sifatsifat selain selain dari sifat-sifat manusia bagi citra tentang Tuhan. Bahkan gagasan orang Yahudi sekali pun, yang tidak

\footnotetext{
28 Abul Kalam Azad, Basic Concepts of The Quran, Terj. Syed Abdul Latif (Hyderabad: Syed Abdul Latif Trust, t.th.), 1.

${ }^{29}$ Ibid.

${ }^{30}$ Ibid., 2.
} 
memperkenankan pemujaan gambaran Tuhan dalam bentuk apapun tidaklah bebas sama sekali dari goresan persamaan semua ini. ${ }^{31}$

Pemikiran manusia belum cukup mumpuni untuk menghindari suatu persamaan semu dengan kondisi manusia ini dengan langsung menuju kepada kecermelangan sifat-sifat Ketuhanan. Bahkan Yesus sendiri ketika memberikan penjelasan tentang pengampunan Tuhan yang bersifat meyeluruh terpaksa menggunakan persamaan atau gambaran semua dengan hubungan yang ada antara Ayah dan Anak, suatu persamaan yang semu yang pada akhirnya menggerakkan kepada para pengikutnya, melalui pendekatan yang salah terhadap makna dan tujuan penggambaran Yesus Kristus ini, yang menempatkan pada kedudukan sebagai anak Tuhan yang sesungguhnya, dan akhirnya pada kedudukan Tuhan sendiri. ${ }^{32}$

Keajaiban Alquran adalah bahwa ia menyibakkan selubung persamaan semu dengan kondisi manusia dari citra Tuhan dan memungkinkan kita untuk mengambil sudut pandang yang melampaui pengalaman manusia mengenai Dia dan sifat-sifatNya.

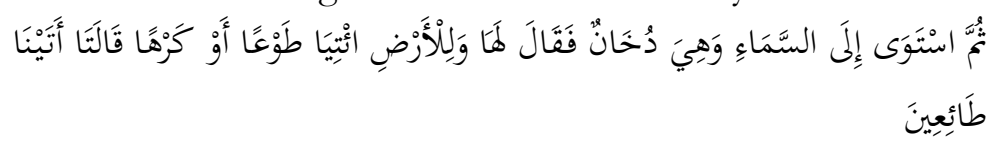

"Kemudian Dia menuju kepada penciptaan langit dan langit itu masih merupakan asap, lalu Dia berkata kepadanya dan kepada bumi: "Datanglah kamu keduanya menurut perintah-Ku dengan suka hati atau terpaksa." keduanya menjawab: "Kami datang dengan suka hati." (QS. Fușșilat [41]: 11)."

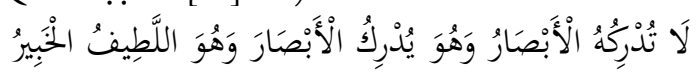

"Dia tidak dapat dicapai oleh penglihatan mata, sedang Dia dapat melihat segala yang kelihatan; dan Dialah yang Maha Halus lagi Maha mengetahui. (QS. al-An`àm [6]: 103)."

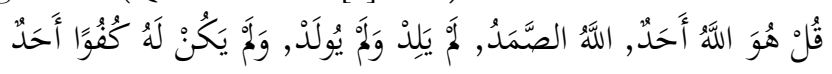

"Katakanlah: "Dia-lah Allah, yang Maha Esa. Allah adalah Tuhan yang bergantung kepada-Nya segala sesuatu. Dia tiada beranak dan tidak pula diperanakkan, Dan tidak ada seorangpun yang setara dengan Dia." (QS. al-Ikhlạ̣ [112]: 1-4)."

Gagasan Alquran mengenai ke-Esa-an Tuhan merupakan suatu kepastian, dan mempunyai sisi positif dan negatif. Sisi positifnya

31 Azad, Konsep Dasar Al-Quran, 4.

32 Ibid. 
adalah bahwa Tuhan hanya Satu dan Esa. Sisi negatifnya ialah bahwa tak satu pun seperti Dia. Manakalah tak suatu pun yang seperti Dia, dengan sendirinya maka sifat apa saja yang dikenakan pada Tuhan tidak dapat dikenakan. Secara bersamaan kepada yang lain. Dalil yang pertama disebut disebut ke-Esaan Hakekat dan dalil berikutnya disebut Keesaan Sifat sebelum munculnya gagasan Quran ini, tekanan lebih banyak diberikan pada Keesaan Tuhan dalam Hakekat dari pada Keesaan Tuhan dalam sifat. Di India, mungkin sejak awal mula, secara tersirat diakui bahwa pemujaan terhadap para pahlawan dan makhluk setengah dewa merupakan hal yang tak dapat dilepaskan dari kebutuhan masyarakat luas, sehingga pemujaan kepada Tuhan dalam Keesaan-Nya atau Ketunggalan-Nya sepenuhnya merupakan hak dan kelebihan golongan elite saja. ${ }^{33}$

"On the other han Qur'an laid so great an emphasis on the Unity of God both in His essence and attributes that it blocked for ever all avenues for polytheism and like abberations. It is this which constitutes its principal contribution to the concept of God." 34

Orang Yahudi misalnya, sudah pasti tidak melaksanakan pemujaan berhala. Meskipun dalam sejarahnya Yahudi pernah mendirikan patung-patung di atas sisa-sisa jasad para Nabi mereka dan menghiasinya dengan gambaran sinar kesucian yang biasanya dikaitkan dengan objek-objek. Dalam ajaran Buhha tidak ada sama sekali ada pemujaan berhala. Sesungguhnya, amanat terakhir sang Budha yang sampai pada kita ialah "jagalah agar kalian tidak memuja abu ku. Jika kalian melakukanya juga, jalan menuju pembahasan dan penyelamatan akan tertutup bagi kalian". Di pihak lain, Alquran memberi tekanan yang yang begitu besar pada Ketunggalan. Tuhan baik dalam hakekat-Nya maupun sifat-sifat-Nya sehingga jalan menuju politeisme dan penyimpangan-penyimpangan sejenis tertutup untuk selama-lamanya. Inilah yang merupakan bagian utama gagasan mengenai Tuhan.

\section{Tuhan, Filsafat, dan Sains Modern}

Para teolog Muslim tradisionalis (ortodoks) yang dipersonifikasi dan dihidupkan kembali oleh Abū Hāamid al-Ghazāili, pemikir revolusioner abad ke-11 yang bisa dikatakan pemikir Islam paling

\footnotetext{
${ }^{33}$ Ibid., 8.

34 Azad, Basic Concepts, 10.
} 
terpengaruh sepanjang masa. Setelah melewati perjalanan intelektual dan spiritual yang Panjang, al-Ghazāili sampai pada kesimpulan bahwa permasalahan yang berkaitan dengan Tuhan atau dengan agama tidak dapat diselesaikan hanya dengan akal..$^{35}$

Mengenai konsepsi Tuhan, para filsuf Muslim percaya bahwa Tuhan yang dipahami dalam kearifan Yunani (Sofia) sama dengan Allah. ${ }^{36}$ Satu abad setelah masa al-Ghazāili yakni Ibn Rushd yang dibesarkan di Andalusia, menyakini bahwa filsafat bisa mensistematisasi wacana rasional tentang Tuhan dan semua masalah penting lainya. Baginya, filsuf adalah representasi dari golongan yang di sebut oleh Alquran yakni sebagai Uli al-Albāb (mereka yang memiliki akar keilmuan yang kuat). Lebih lanjut, ia mengajukan seperangkat prinsip berikut ini untuk meringkas doktrin teologisnya:

1. Keberadaan Allah sebagai pencipta dan Pemelihara alama

2. Keesaan Allah.

3. Sifat-sifat Allah berupa mengetahui, menguasai, bebas mengatur, mendengar, melihat, dan berfirman dinyatakan dalam Alquran.

4. Keunikan dan ketidakmungkinan untuk disaingi, sebagaimana dijelaskan dalam QS. al-Shūrā [42]: 9 tidak ada yang menyerupaiNya.

5. Pencipta dunia meskipun manusia tidak mengetahui bagaimana dan kapan dunia diciptakan.

6. Kebenaran kenabian.

7. Keadilan Allah.

8. Kebangkitan fisik pada Hari Akhir.

Menurut Nidhal Guessoum, beberapa prinsip tertentu (terutama yang ketiga dan yang terakhir) kurang bisa mencerminkan gagasan cemerlang atau penafsiran Ibn Rushd yang tampak dalam karyakaryanya. Meski demikian Ibn Rushd masih jauh dari gambaran 'filsuf sesat' yang sering dihujat kaum tradisionalis, sebab untuk dasar-dasar doktrinal ini, pemikiranya pantas diadopsi sebagai model integrasi yang sejati.

35 Nidhal Guessoum, Islam dan Sain Modern, Terj. Maufur (Bandung: Mizan Media Utama, 2014), 65.

${ }^{36}$ Karen Armstrong, A History of God: The 4000-Year Quest of Judaism, Christianity, and Islam (New York: Alfred A. Knopf, 1993), 170. 
Sejarah keterpengaruhan para filsuf abad pertengahan Spanyol (Ibn Rushd dari kalangan Muslim dan Maimonides dari Yahudi) yang berkaitan dengan teolog Kristen dan filsuf juga sering dibahas oleh beberapa penulis. Pembahasan mengenai Ketuhanan, seorang penulis ${ }^{37}$ menemukan kemiripan mencolok antara delapan prinsip Ibn Rushd di atas dan 13 komponen iman yang digagas Maimonides berikut ini yakni:

1. Keberadaan Tuhan.

2. Keesaan Tuhan.

3. Ke-nirjasad-an Tuhan.

4. Keabadian Tuhan.

5. Larangan penyembahan berhala.

6. Kebenaran kenabian.

7. Musa adalah Nabi teragung.

8. Sumber ilahiah dari kebenaran.

9. Kebenaran abadi Taurat.

10.Pengetahuan Tuhan atas perbuatan manusia.

11.Keadilan hukum Tuhan.

12.Tuhan akan mengirim Mesiah dan.

13. Kebangkitan orang mati.

Sains modern telah memunculkan tiga teori yang sangat penting dan memberi dampak signifikansi terhadap konsepsi dan kepercayaan terhadap konsep Ketuhanan. Ketiga teori tersebut adalah pertama, teori evolusi Darwin (melalui seleksi alam). Kedua, teori kosmologi Bing Bang dan Ketiga, teori Mekanika Kuantum (MK) yang merupakan deskripsi dari dunia mikrofisika.

\section{Alquran, Transendentalisme dan Antropomorfisme}

Salah satu gagasan utama Azad dalam konsep ketuhanan adalah upayanya dalam mendedah konsep ketuhahanan Alquran yang berbeda dari konsep-konsep ketuhanan lainnya. Seperti dijelaskan sebelumnya, Azad menilai bahwa beberapa sarjana Barat telah keliru dalam berargumen bahwa teologi monoteisme merupakan produk dari sebuah proses evolusi. ${ }^{38}$ Sebaliknya, Azad justru berdalih bahwa monoteisme merupakan asal muasal (origins) teologi dalam sistem

\footnotetext{
37 Rainer Nabilek, "Muhammad Syahrur, ein "Martin Luther" des Islam", Imamo, 6/23-24, autumun/winter (2000), 73-74.

38 Azad, Basic Concept, 2.
} 
kepercayaan manusia. Dia merujuk beberapa temuan lain, yang berasal dari berbagai benua, mulai dari Australia Tenggara, beberapa pulau di samudra Pasifik, orang-orang primitive di Amerika Utara, Mesir kuno, Irak, dan Mohenjadaro semuanya menunjukan bahwa kepercayaan terhadap yang Esa bukan merupakan hasil dari proses evolusi. Demikian juga dengan tradisi Semitik, suku-suku Bangsa Semit, sejak awal mula keberadaannya, mereka percaya akan satu Tuhan (an Unseen Supreme Being). Demikian juga dengan beberapa penilian lain paska perang dunia pertama juga menunjukan bahwa keyakinan paling awal yang dianut oleh manusia adalah system teologi monoteisme. ${ }^{39}$

Lebih jauh, Azad menjelaskan bahwa dengan berdasar pada fakta-fakta monoteisme tersebut, maka justru politeisme itulah yang telah mengalami proses evolusi. Azad menggambarkan bahwa proses evolusi terjadi karena ketidakmampuan manusia menggapai sebuah pengetahuan utuh tentang Tuhan. Maka munculah atribut-atribut ketuhanan yang bersifat profan untuk memudahkan manusia memahami Tuhan-nya. Atribusi ketuhanan itu pada gilirannya menjadi sebuah keyakinan yang mengakar pada sebuah formasi teologi. Pada tahap inilah proses 'humanizing God' (memanusiakan Tuhan) terjadi.

Azad lebih jauh menegaskan bahwa "Adam was created with light within, but his progeny frittered it away and let in darkness instead ${ }^{40}$ (Adam telah diciptkan dengan cahaya, namun keturunannya menjauhkannya dan menempakan mereka dalam kegelapan)." Pernyataan ini menandaskan bahwa pada permulaannya, manusia berada dalam cahaya monoteisme, yang kemudian teologi ini mengalami penyimpangan seiring dengan perkembangan manusia. Hal ini dikuatkan juga oleh tradisi-tradisi yang telah mengakar kuat di berbagai daerah seperti Mesir, Yunani, India, Cina dan Iran yang kesemuanya menyatakan bahwa manusia pada mulanya dituntun oleh "Alam."

Azad cukup teliti untuk melihat akibat dari kesenjangan ini yang kemudian melahirkan cara pandang akan Tuhan yang berbeda, yaitu lahirnya cara pandang pemujaan terhadap atribut-atribut Tuhan dan bukan pada eksistensi Tuhan itu sendiri. Pada tahap ini, intelektualitas manusia tertutup oleh sensivitasnya. Pemahamannya tidak mampu menembus garis batas terdepan yang pada akhirnya tidak bisa untuk

\footnotetext{
${ }^{39}$ Ibid.

40 Ibid., 3.
} 
memahami sesuatu yang Absolut. Ketika mereka mencoba untuk memahami sesuatu yang tak tampak, mereka akan jatuh pada proses visualisasi yang diserupakan dengan kualitas-kualitas yang ada pada dirinya sendiri. Padahal keduanya merupakan hal yang jelas berbeda. ${ }^{41}$

Dari titik ini Azad kemudian memperhatikan tiga kecenderungan yang selaras satu sama lain: yaitu pergerakan dari antropomorfisme ke transendentalisme, dari politeisme kembali ke monoteisme, dan dari cara pandang bahwa Tuhan yang mengagumkan dan menakutkan ( $a$ God of awe and terror) ke cara pandang tentang Tuhan yang Maha Kasih (a God of love). ${ }^{42}$

Terhadap kecenderungan yang terakhir, Azad memberi pengantar pertanyaan: mengapa awal konsep manusia dalam menghargai Tuhan itu berangkat dari keyakinan bahwa Tuhan itu maha mengagumkan dan maha menakutkan? Terhadap pertanyaan ini, Azad menjawab dengan jelas bahwa semua itu kembali kepada konsepsi manusia atas Tuhan. Bahwa konsepsi manusia pada mulanya lebih didominasi dan dikonstruksi atas keyakinan akan Tuhan yang menakutkan. Konsepsi akan Tuhan yang maha kasih telah tertutup oleh nalar ketakutan dan kekuatan Tuhan yang dengan mudah mampu untuk menghancurkan. Pada tahap inilah konsepsi manusia akan Tuhan lebih dikonstruksi pada paham destruktif daripada cara pandang konstruktif. Karena kemampuan mereka memahami Tuhan dari fenomena alam, maka, adanya kilat dan cahaya petir di tengah gelapnya awan, erupsi vulkanis gunung, gempa bumi, banjir, dan badai merupakan bentuk-bentuk yang divisualisasi sebagai kekuatan Tuhan yang maha menghancurkan.

Pada titik inilah kemudian Azad mengenalkan konsep ketuhanan yang ada dalam Alquran. Menurutnya konsep ketuhanan yang digambarkan dalam Alquran berbeda dengan konsep-konsep ketuhanan lain yang ada. Ini artinya, Alquran turut merespon konsepsi-konsepsi ketuhanan yang eksis pada masanya. Azad menyebut,

"prior to the delivery of the Qur'an, the highest that the human intellect could achieve was to think of God without any symbolic aid... the peculiarity of the Qur'an is that it lifts the veils of anthropomorphic similitudes from across the vision of God and allows us to take a transcendental view of Him in His attributes." 43

\footnotetext{
41 Ibid., 3-4.

42 Ibid.

43 Ibid., 5.
} 
Sekilas, Azad Nampak hendak memperlihatkan distingsi Alquran tentang konsep ketuhanan yang berbeda dengan yang lain. Namun pada gilirannya, dia mengakui bahwa antara dimensi kemanusiaan dan dimensi ketuhanan ada perantara kreatif manusia yang disebutnya sebagai atribut ketuhanan. Namun, berbeda dengan yang lain, Alquran lebih menempa jalan tengah di mana atribut ketuhanan tidak sampai menjatuhkan manusia pada antropomorfisme, juga tidak menihilkan atribut-atribut ketuhanan agar tidak terjebak pada paham nihilisme.

Terhadap paham yang terakhir ini, Azad mencontohkan Upanisad yang mengedepankan proses penegasian total: 'Nēti - Nēti.' Paham ini, menurut Azad, jauh melebihi pandangan transendentalisme karena pada akhirnya paham ini sampai pada tahap peniadaan (nullification), dan justru menjauhkan diri dari teologi yang positif.

Kutipan berikut ini dengan jelas bisa menggambarkan konsepsi ketuhanan dalam Alquran yang dipahami oleh Azad, ${ }^{44}$

"the Qur'an avoids both the extremes and follows a line of its own. It pursues a path along which we not only get a transcendental vision of God, but feel competent to dispel the anthropomorphic atmosphere that may attempt to close round it. It affirms individual attributes, one by one; but it prevents each attribute developing any anthropomorphic touch. 'He is the Living, the Almighty, the Creator, the Merciful, the All Seing, the All Hearing, the All Knowing,' and so forth. Not merely this, the Qur'an employs here and there, without any hesitation, every form of figurative expression admissible in literature. But it makes it clear that nothing may be compared to God. His living is not like our living; His seeing or hearing or knowing is ot like ours. The metaphor of hand may be used to denote His power and forgiveness, and that of 'Arsh or Throne to denote His Majesty and His All-Embracing control of the Universe. But the sense is not the same as may be formed of these in our mind in relation to human activity."

Dari keterangan ini, Azad dengan jelas menerangkan bahwa posisi Alquran berbeda dalam merespon konsepsi ketuhanan. Alquran berada dalam poros tengah dengan tetap mengakui adanya atributatribut ketuhanan, karena dari sanalah jalan untuk memahami Tuhan bisa dituai. Namun, atribut itu tidak diposisikan pada titik akhir, yang

44 Ibid., 7. 
bisa menjerumuskan seseorang pada teologi anthropomorfisme. Karena di sisi lain, Alquran juga mengintrodusir paham penegasian dengan mengutip beberapa ayat, seperti "tidak ada yang seperti Dia" (QS. Fușșilat [41]:11), "tidak ada yang memebri penglihatan kepadaNya, namun Dia yang mengambil semua penglihatan” (QS. al-An'am [6]:104), dan "Dialah Tuhan Yang Maha Esa, Tuhan yang bergantung segala sesuatu kepada-Nya, Tuhan yang tidak beranak, dan tidak pula diperanakkan, Tuhan yang tidak ada sesuatu yang setaradengan-Nya" (QS. al-Ikhlạ̄ [112]: 1-4). ${ }^{45}$

\section{Kesimpulan}

Dari paparan di atas, dapat digarisbawahi bahwa Abdul Kalam Azad merupakan pemikir yang hebat pada masanya yang mempunyai gagasan-gagasan yang baru tentang ajaran Islam khususnya dalam bidang tafsir Alquran yang diramu dengan keilmuan-keilmuan modern. Salah satu terobosan yang cukup penting, yang ditulis dalam artikel ini adalah bahwa Abdul Kalam Azad telah berhasil menunjukan posisi Alquran dalam konsep ketuhanan di antara konsep-konsep lain tentang Tuhan. Baginya, Alquran berada dalam poros tengah yang menghindari dari terjerumus pada titik ekstrim tertentu, khususnya, dari kelompok antropomorfisme dan nihilisme. Alquran dalam pandangan Azad mengetengahkan konsep ketuhanan yang tidak terjerembab pada atribut-atribut ketuhanan, dan pada saat yang sama juga tidak melakukan peniadaan atribut secara total. Atribut-atribut tersebut diapropriasi oleh Alquran namun tetap dengan menjaga jarak pemahaman bahwa atribut tersebut bukanlah Tuhan itu sendiri. Sebaliknya, Alquran juga mengapropriasi 'peniadaan' atribut ketuhanan dalam konteks untuk memperlihatkan Tuhan yang utuh, murni tanpa simbol-simbol atributif yang dilekatkan kepada-Nya. Pada titik inilah, dengan berbekal arkeologi keilmuan, Azad mampu menghadirkan posisi Alquran yang berada dalam poros tengah dalam diskursus ketuhanan.

\section{Daftar Pustaka}

Ali, Mukti. Alam Pikiran Islam Modern di India dan Pakistan, cet. III. Bandun; Mizan, 1996.

45 Ibid., 6-7. 
Alvi, Hayat. "The Islamic Principles of Social Justice: Maulana Abul Kalam Azad and Nonviolent Civil Disobedience." Contemporary Review of the Middle East, 2, 1\&2, (2015).

Armstrong, Karen. A History of God: The 4000-Year Quest of Judaism, Christianity, and Islam. New York: Alfred A. Knopf, 1993.

Azad, Abul Kalam, Hikmah al-Fatiha: konsep Tuban dalam Alquran. Diterjemahkan oleh Tim Mushaf. Depok: Mushaf, 2007. - Basic Concepts of The Quran, Terj. Syed Abdul Latif. Hyderabad: Syed Abdul Latif Trust, t.th. . Konsep Dasar Alquran. Diterjemahkan oleh Ary Anggari H. Jakarta: Pustaka Firdaus, 1991.

. The Tarjuman Al-Qur'ann. Diterjemahkan oleh Syed Abdul latif. Hiderabad: Syed Abdul Latif Trust for Qur'anic \& Other Cultural Studies, 1962.

Douglas, Ian H. "Abul Kalam Azad and Pakistan A Post-Bangladesh Reconsideration of an Indian Muslim's Opposition to Partition." Journal of the American Academy of Religion, vol. XL, no. 4 (1972).

Guessoum, Nidhal. Islam dan Sain Modern. Diterjemahkan oleh Maufur. Bandung: Mizan Media Utama, 2014.

Habib, S. Irfan. "Maulana Abul Kalam Azad and His Ideas about the National Education System." Contemporary Education Dialogue, 12, 2 (2015).

Izutsu, Toshihiko. God and Man in the Qur'an Semantics of the Qur'anic Weltenschaunng. Tokyo: Keio University, 1964.

Kamali, S.A. "Abul Kalam Azad's Commentary on the Qur'an." The Muslim World, Vol. 49, No. 1 (1959).

Marcu, Margareta. Islam dan Modernisasi. Diterjemahkan oleh A. Jainuri. Surabaya: Usaha Nasional, 1982.

Nasution, Harun. Pembaharuan dalam Islam, cet 8. Jakarta; Bulan Bintang, 1991.

Noldeke, Theodor, Friedrich Schwally, Gotthelf Bergstrasser, Otto Pretzl. The History of the Qur'an. diedit dan diterjemahkan oleh Wolfgang H. Behn. Leiden: Brill, 2013.

Rahman, Fazlur. Major Themes of the Qur'an. Chicago: The University of Chicago Press, 2009.

Rajput, A.B. Maulana Abul Kalam Azad. Lahore, Lion Press, 1957.

Willis, John. "Debating the Caliphate: Islam and Nation in the Work of Rashid Rida and Abul Kalam Azad." The International History Review, 32, 4 (2010). 